\title{
COMMENTARY
}

\section{A New World Health Era}

\author{
Ariel Pablos-Méndez, ${ }^{a}$ Mario C Raviglione ${ }^{b}$
}

Unprecedented economic progress and demands for social protection have engendered an economic transition in health in many low- and middle-income countries, characterized by major increases in domestic health spending and growing national autonomy. At the global level, development assistance is refocusing on fragile states, the poorest communities, and cooperation on global public goods like health security, technical norms, and innovation. Intergovernmental organizations like WHO need the wherewithal and support to provide leadership and to properly advance this new world health era.

B etween 2010 and 2015, development assistance for health (DAH) reached over US\$30 billion a year, ${ }^{1}$ and the Millennium Development Goals (MDGs) ${ }^{2}$ helped drive unprecedented gains in development and health equity. ${ }^{3}$ While those accomplishments are cause for celebration, ${ }^{4}$ DAH budgets have tightened ${ }^{1}$ as the world confronts new health challenges, and the global health community is worried about human rights reversals by recently elected populist governments. ${ }^{5}$ Health financing at the country level looks more promising and could be the basis for a new world health era.

\section{AN ECONOMIC TRANSITION IN HEALTH}

After centuries of flat incomes per capita, the world has experienced a 20 -fold increase in gross domestic product (GDP) during the last 50 years. ${ }^{6,7}$ The majority of countries that were considered low-income in 1990, including Bolivia, Bangladesh, and the Republic of Congo, have moved to lower-middle or middle-income status. ${ }^{8}$

Health spending is very closely correlated with GDP and it accounts for an expanding fraction of any growing economy. ${ }^{9}$ While that is often a fiscal and political headache for richer countries, for a growing number of lower-income countries the increase in health resources has the potential to cover the average cost per capita of essential lifesaving commodities and services. ${ }^{9}$

As DAH plateaued in recent years, ${ }^{1}$ many lowincome countries saw total health spending grow at $10 \%$ per year (based on data from National Health Accounts compiled by USAID in 2015). Public and private domestic resources now dwarf DAH (Figure 1). The growth of health spending, however, follows a surge in the demand for health services that is often met by unregulated private services paid out-of-pocket, an inefficient and regressive form of health financing. ${ }^{11}$ This

a Columbia University Medical Center, New York, NY, USA. Formerly the Assistant Administrator for Global Health, United States Agency for International Development, Washington, DC, USA.

b University of Milan, Italy. Formerly Director of the Global Tuberculosis Programme, World Health Organization, Geneva, Switzerland.

Correspondence to Ariel Pablos-Méndez (ap39@cumc.columbia.edu). transition is linked to the economics of countries at different stages of development. Thus, these changes have already occurred in several countries and may not be complete in others by 2030.

\section{A HISTORICAL PENDULUM IN THE POLITICAL ECONOMY}

Political economy is the branch of social science that studies the relationships between individuals and society and between markets and the state. ${ }^{12}$ The liberal forces galvanized by the Enlightenment, the 18th century philosophical movement in Europe that promoted freedom, fraternity, solidarity, and equality, have brought unprecedented well-being to our civilization, ${ }^{13}$ but progress has not been linear. Periodic structural shifts in the political economy, whether arising from global crises or national elections, bring new challenges and opportunities and change the ways in which the health agenda is advanced.

After World War II, with the end of European colonialism, what was known as geographic or "tropical medicine" became firmly established as "international health," with newly created international agencies and new and assertive nations committed to primary health care (Figure 2). ${ }^{14}$ The World Health Organization (WHO) was the unquestionable leader of the period, but its uniqueness started being challenged in the early 1990s. ${ }^{15-18}$

At that time, after the collapse of the Soviet Union, the Washington Consensus - the set of market economic ideas supported by the International Monetary Fund and the World Bank-downplayed national government and promoted neoliberal policies, i.e., a strong market-based approach to globalization, decentralization, and privatization. ${ }^{19}$ New philanthropy and the AIDS movement were additional ingredients of what became "global health." ${ }^{20}$ WHO's influence waned ${ }^{21,22}$ amidst a plethora of new public-private partnerships advancing donor-supported initiatives against AIDS, tuberculosis, malaria, and vaccine-preventable diseases. ${ }^{14,23}$ While some experts worried about open- 
FIGURE 1. Financing Trends in Developing Countries, 2000-2014 (in US\$, billions, 2013 prices)

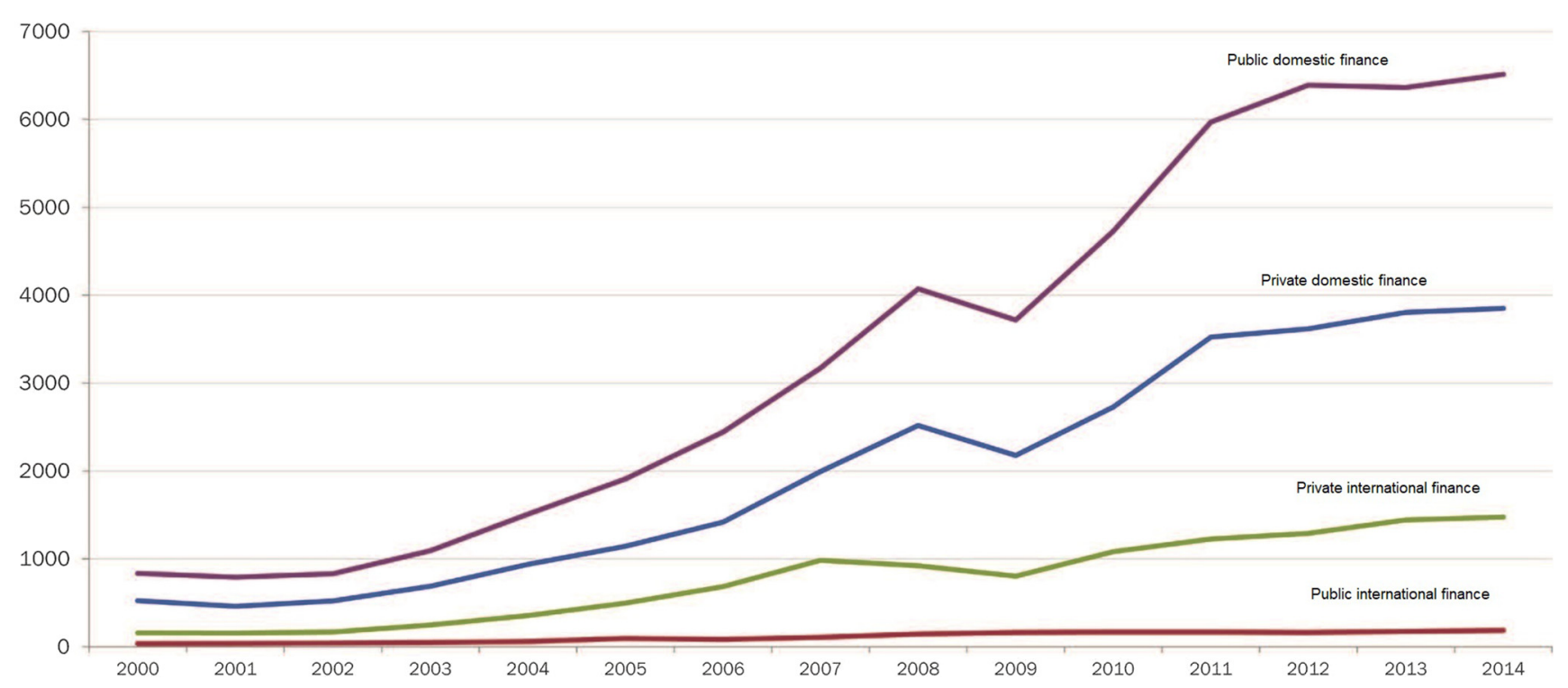

Note: Public domestic finance is defined as total government revenue. Gross-fixed capital formation by the private sector was used as an indicator for private domestic finance. Private international finance is the sum of foreign direct investment, portfolio equity and bonds, commercial banking and other lending, and personal remittances. Public international finance equals the total official flows (official development assistance and other official flows).

Source: United Nations Research Institute for Social Development (2016). ${ }^{10}$

source anarchy and undue influence, ${ }^{24}$ these global partnerships contributed to achieving several MDGs.

We are at a new inflexion point. The Great Recession of 2008 caused a reduction in global GDP and global trade for the first time in half a century. ${ }^{25}$ While markets have recovered since, their failure caused ongoing social pain and revealed severe inequalities, ${ }^{26}$ leading to economic insecurity and growing political demand for social protection and popular rejection of globalization. ${ }^{5,27}$

National governments are reasserting themselves, in extreme cases with protectionism and xenophobia. ${ }^{28}$ Countries that responded to the crisis with fiscal austerity have faced a wave of antiestablishment, ethnopopulist elections not seen since the 1930s. ${ }^{29}$ This creates many domestic problems of its own and pushes back against the international cooperation and altruism that characterized the golden era of global health. In the long run, populism is no substitute for sound governance and it carries risks. ${ }^{30}$ Good technical and political leadership is needed to address the underlying economic inequalities responsible for the social turmoil seen in many countries.

\section{A NEW WORLD HEALTH ERA?}

Economic growth and increasing health spending in many "developing" countries, along with stagnant DAH and a wave of populist policies, pave the way for a number of profound changes in our field (Table). At the national level, there will be more country ownership and domestic resource mobilization (DRM), with an increasingly feasible possibility of achieving universal health coverage (UHC). At the global level, the power of DAH is diluted and likely to refocus on fragile states and global public goods with benefits to all countries (see below). As a result, member-state organizations like WHO and the World Bank, in coordination with other influential public and private actors, have new opportunities to address existing and emerging health challenges. ${ }^{31}$ Many existing organizations at the global and national level will adjust the role they play and how they fund their work in this new world health era.

\section{Domestic Resource Mobilization}

With emerging economies growing, the Third International Conference on Financing for Development, held in Addis Ababa, Ethiopia,

Health spending
accounts for an
expanding
fraction of total
spending for any
growing economy.

Good technical and political leadership is needed to address the underlying economic inequalities responsible for the social turmoil seen in many countries. 
FIGURE 2. A New Chapter in International Health History

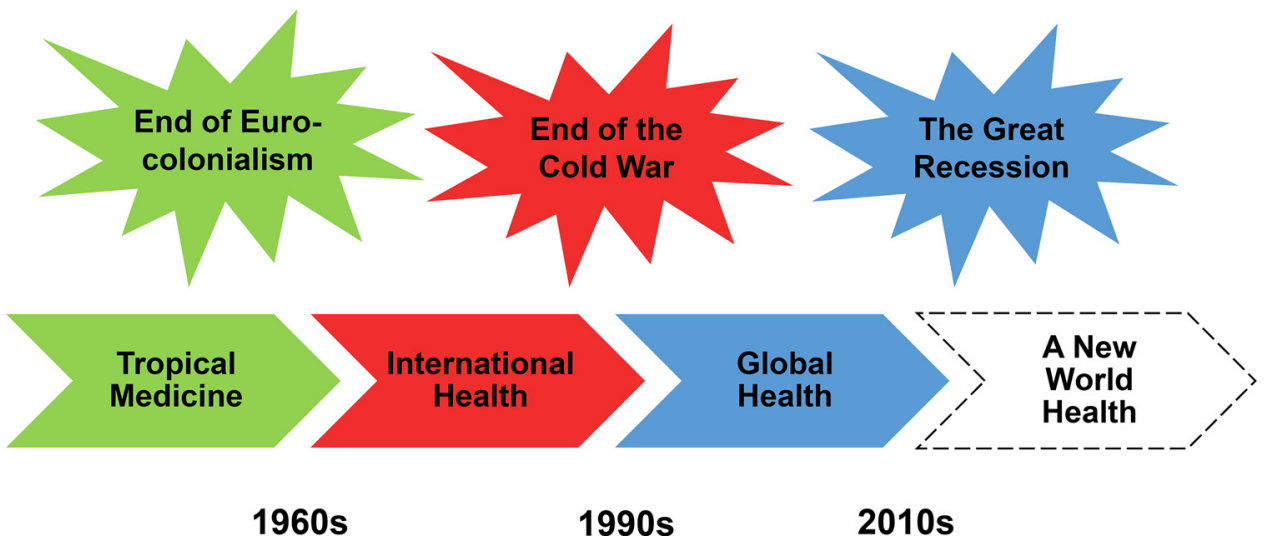

Note: This graph is only a didactic tool; historical periods often overlap and vary from one country or region to another, and many components of one period carry over to future ones.

\section{Universal health coverage means access for all to appropriate health services without financial hardship.}

positioned DRM at the heart of the post2015 agenda. $^{32}$ The World Bank estimates that simply bringing laggards to the median government revenue level by increasing tax ratios to the median $23 \%$ of GDP in low- and middleincome countries would add US\$26 billion each year for public expenditure in health. ${ }^{33}$ In addition, increasing the government budget allocation for health to just the median level of $10 \%$ would generate an extra $\$ 50$ billion each year. ${ }^{33}$ Tobacco taxes can contribute to general taxation and also reduce one of the main drivers for chronic diseases. Additional DRM possibilities include leveraging concessionary loans from development banks (e.g. the Global Financing Facility), ${ }^{34}$ innovative financing (e.g., social impact bonds, loan guarantees), ${ }^{35}$ and shaping responsible markets. ${ }^{36}$ Countries like Ghana, Ethiopia, and Rwanda have shown it is possible to increase health budgets significantly.

\section{Universal Health Coverage}

As shown in Figure 1, health spending is rising and will likely continue to do so as GDP expands. In the absence of government policy on public or private insurance, health spending is often paid out-of-pocket by individuals, which sends millions of families back into poverty. ${ }^{37,38}$ Such expenditures account for $50 \%$ of total health spending in most African countries and up to $80 \%$ in large South Asian nations-versus less than $20 \%$ in most countries of the Organisation for Economic Co-operation and Development
(OECD). ${ }^{11}$ In response to this growing challenge, UHC is becoming the organizing principle for health systems everywhere. ${ }^{39,40}$

UHC means 3 things: (1) access for all to (2) appropriate health services (at a minimum, health promotion and primary care, with additional services depending on local epidemiology and economics), and (3) without financial hardship (financial hardship is defined as $25 \%$ or more of total household expenditures spent on out-of-pocket health expenditures). ${ }^{37}$ UHC is not about donors buying health insurance but about national governments organizing health financing in equitable, prepaid risk pools. ${ }^{32}$ The services covered under UHC should be not only curative but also public health and preventive, like immunization, nutrition, family planning, and road safety interventions. Indeed a major challenge is to prioritize such services in the face of huge demand for expensive tertiary care for urban elites. According to the International Labour Organization, over 60 countries have achieved UHC and several more are halfway in their decades-long reforms (Figure 3). ${ }^{41}$ Many countries, especially in Africa, are asking for technical assistance to reorient their health sector toward UHC.

A global movement toward the progressive realization of UHC is unfolding. ${ }^{37,42}$ Following the World Health Report 2010, ${ }^{37}$ the United Nations (UN) General Assembly passed a resolution supporting UHC, ${ }^{43}$ which is now enshrined in the Sustainable Development Goal (SDG) targets for 2030. ${ }^{44}$ The G7 and the G20-the international 
TABLE. Changes in the Health Field, 1960s to Present Day

\begin{tabular}{|c|c|c|c|}
\hline Period & $\begin{array}{l}\text { International Health } \\
1960 \text { s to } 1990 \text { s }\end{array}$ & $\begin{array}{l}\text { Global Health } \\
1990 \text { s to circa } 2015\end{array}$ & $\begin{array}{l}\text { New World Health } \\
2008 \text { to Present }\end{array}$ \\
\hline Geopolitical origins & $\begin{array}{l}\text { End of European Colonialism } \\
\text { with new voting members in a } \\
\text { newly formed UN }\end{array}$ & $\begin{array}{l}\text { End of the Cold War (and the Soviet } \\
\text { Union), freer trade, Internet, and } \\
\text { AIDS }\end{array}$ & $\begin{array}{l}\text { Financial markets crash, } \mathrm{OECD} \\
\text { recession, and emergent developing } \\
\text { economies }\end{array}$ \\
\hline Political economy tone & $\begin{array}{l}\text { Cold War with East-West } \\
\text { divide }\end{array}$ & $\begin{array}{l}\text { "Government is the problem," mar- } \\
\text { kets and civil society the solution }\end{array}$ & $\begin{array}{l}\text { Reassertion of nation-state and } \\
\text { demands for social protection }\end{array}$ \\
\hline Predominant approach & $\begin{array}{l}\text { Primary health care, "Health } \\
\text { for All," and solidarity as uni- } \\
\text { versal principles and } \\
\text { movements }\end{array}$ & $\begin{array}{l}\text { Top-down programs and PPPs to fight } \\
\text { key diseases of poverty in developing } \\
\text { countries }\end{array}$ & $\begin{array}{l}\text { Grand convergence between North } \\
\text { and South, progressive realization } \\
\text { of UHC and global health security }\end{array}$ \\
\hline International cooperation & $\begin{array}{l}\text { Colored by foreign affairs } \\
\text { (East-West competition, with } \\
\text { exceptions like smallpox } \\
\text { eradication) }\end{array}$ & $\begin{array}{l}\text { Explosion of NGOs, PPPs, and new } \\
\text { philanthropy tackling the MDGs in } \\
\text { poor countries }\end{array}$ & $\begin{array}{l}\text { Assertive but interdependent nation- } \\
\text { states sign up to the universal SDGs }\end{array}$ \\
\hline Governance & $\begin{array}{l}\text { WHO takes center stage in the } \\
\text { UN architecture }\end{array}$ & $\begin{array}{l}\text { "Open source anarchy" (WHO's } \\
\text { authority diluted) }\end{array}$ & $\begin{array}{l}\text { Sovereign states reasserted; } \\
\text { opportunity for WHO }\end{array}$ \\
\hline Private sector & $\begin{array}{l}\text { Essentially proscribed from } \\
\text { UN settings and agenda }\end{array}$ & $\begin{array}{l}\text { Rise in prominence both through PPPs } \\
\text { and philanthropy, IT enables global } \\
\text { communications }\end{array}$ & $\begin{array}{l}\text { Half of the health sector provision } \\
\text { and growing markets in emerging } \\
\text { economies }\end{array}$ \\
\hline Civil society and community role & $\begin{array}{l}\text { Empowerment of communities } \\
\text { after Alma-Ata Declaration of } \\
1978\end{array}$ & $\begin{array}{l}\text { Growing activism, especially linked } \\
\text { with HIV/AIDS }\end{array}$ & $\begin{array}{l}\text { National NGOs very important } \\
\text { despite closing space in some } \\
\text { countries }\end{array}$ \\
\hline
\end{tabular}

Abbreviations: DAH, development assistance for health; IT, information technology; MDGs, Millennium Development Goals; OECD, Organisation for Economic Co-operation and Development; PEPFAR, U.S. President's Emergency Plan for AIDS Relief; PPPs, public-private partnerships; SDGs, Sustainable Development Goals; UHC, universal health coverage; UN, United Nations; USAID, United States Agency for International Development; WHO, World Health Organization.

summits where leaders from the world's advanced and emerging economies meet to discuss critical global issues-support UHC, and a UHC Alliance has been born to foster and track progress to 2030. At the December 2017 Universal Health Coverage Forum in Tokyo, Japan's Prime Minister Shinzo Abe pledged US\$2.9 billion for UHC while UN Secretary-General António Guterres announced UHC will be the subject of a high-level meeting at the UN General Assembly in $2019,{ }^{45}$ giving impetus to WHO's goal of expanding health coverage to an additional 1 billion people in 5 years. ${ }^{37}$

\section{Development Assistance for Health}

This new world health era will be driven by DRM rather than DAH and that will affect the role played by governments, industry, and international organizations. ${ }^{46}$ Diluted by domestic growth, DAH today accounts for less than $20 \%$ of the total health spending even in Africa ${ }^{47}$ and is shrinking in most recipient countries. It is already below $1 \%$ in middle-income countries like India. Donors are graduating successful countries from external assistance, ${ }^{48}$ with the goal of concentrating DAH in the poorest nations by $2030 .{ }^{40}$ These international donors also have a window of opportunity to support the transformation of health systems toward prioritizing prevention and primary care in UHC; most DAH programs are moving from service provision to capacity building and technical assistance. ${ }^{48}$

\section{Global Public Goods}

In this context, DAH should shift progressively to support global public goods ${ }^{49}$ like global health
The new world health era will be driven by domestic resource mobilization rather than development assistance.

Development assistance should shift progressively to support global public goods. 


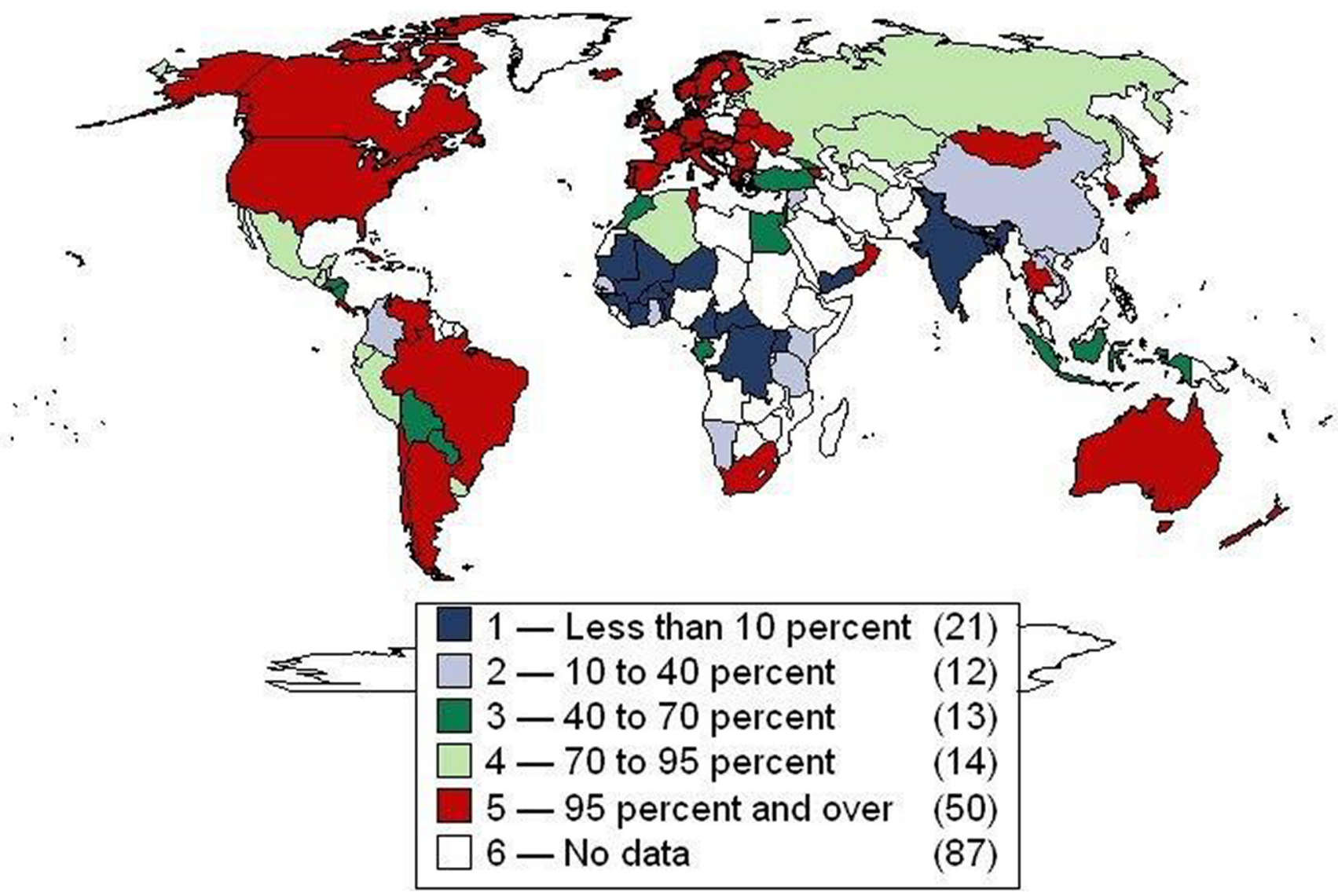

\footnotetext{
a The graph assesses the proportion of the population affiliated with national health insurance or social, private, or micro- insurance schemes. Source: This graph was first published in Garret $(2009)^{39}$ and later updated in the International Labour Organization (2017). ${ }^{41}$
}

security, international norms, pooled procurement, and research and development (particularly on diseases of poverty). While the Ebola epidemic galvanized donors to improve global health security, ${ }^{50-52}$ the other areas mentioned deserve equal and sustained attention. Funding global public goods makes sense as DAH dollars in countries decline or are diluted by DRM, and given their broader benefits including to the citizens of donor countries. Led by BRICS countries (Brazil, Russia, India, China, and South Africa), these and many other "emerging" economies are also contributing valuable research and development and other innovations in South-South collaboration. ${ }^{53}$

The MDGs helped generate increased political support and funding against child and maternal mortality, HIV/AIDS, tuberculosis, and malaria. The end result was major reductions in mortality and suffering from these conditions. ${ }^{2}$ However, chronic noncommunicable diseases (NCDs) are a neglected area in global health that is ripe for creative action. NCDs are now the leading cause of death worldwide, ${ }^{54}$ and the epidemiologic transition is proceeding rapidly in Africa. ${ }^{55}$ Yet investments and effective solutions have lagged. 1,56 UHC, backed by targeted DAH, offers an opportunity to tackle NCDs with multisectoral initiatives as predicated by the SDG framework. ${ }^{57}$

\section{The Private Sector and Civil Society}

During the 1970s, the private sector was nearly absent from public health circles, though it was already playing a growing role in the provision of medicines and clinical services. At the turn of the millennium, many public-private partnerships 
(PPPs), like Gavi or the Global Alliance for TB Drug Development, were created to address market failures in the development and supply of drugs and vaccines. The change brought energy, creativity, and progress for orphan drugs and the MDGs.

PPPs 2.0 will be less top-down and more engaged in local markets and political economy, where the private sector accounts for half of total health expenditures. ${ }^{1}$ Private practitioners, formal or informal, already play a prominent role in service provision. ${ }^{58}$ Governments will need stronger stewardship capacity to regulate mixed health systems $^{59}$ and shape markets to ensure quality and equity. ${ }^{31}$ As countries move toward UHC, governments will need to prioritize public financing for primary health care and population-based prevention, besides provision of curative services. ${ }^{60}$

Civil society, uniting forces with public health officials and political leaders, dramatically changed the response to HIV/AIDS, making it a top priority at all levels and driving unprecedented growth of DAH for lifesaving interventions. ${ }^{61}$ Civil society organizations will continue to play a critical role even as some authoritarian governments try to close the space for their work. If anything, the moral and innovative voice of NGOs, community organizations, and other civil society actors is a public good that will further grow in importance to guide multisectoral policy for UHC and to hold politicians accountable to the citizenry. ${ }^{62}$

While health is only one of 17 SDGs, the principle of partnership and new approaches to multisectoral collaboration will remain key in this new era. Interdependence requires closer cooperation and common aims among relevant UN agencies, development banks, professional organizations and, yes, the private sector. WHO governing bodies are exploring more inclusive engagement of non-state actors without compromising their ethics and neutrality. ${ }^{63}$

\section{The World Health Organization}

As the premier UN agency for health, WHO figures prominently in historical analyses of international health. ${ }^{14,22}$ With greater emphasis on domestic resources, assertive member states, and the centrality of national health systems, this new era offers an opportunity to better define the role of intergovernmental organizations such as WHO and the World Bank. ${ }^{64}$ That is a challenge for the recently elected WHO Director-General ${ }^{65}$ given the complexity the international arena accrued in the previous era ${ }^{18}$ and the internal organizational challenges posed by decentralized management and constrained budgets ${ }^{66}$ relative to expectations. Tellingly, the new Director-General is from Africa and was elected for the first time by all member states, giving him, in principle, unprecedented political capital to forge ahead with his priorities, including UHC and global health security. Unlike previous eras, this new agenda has been forged and embraced by the World Bank Group as central to human capital and economic development. $^{44}$

To succeed in a new world health era and deliver on the SDG agenda, WHO will need to act on several fronts and focus on its comparative advantages. Firstly, while technical assistance to countries and strategic leadership may not be unique to WHO, ensuring their adequate and neutral provision to member states is key to its mission. WHO needs to be able to swiftly declare public health emergencies of international concern and help improve the world's capacity to detect and respond to pandemic threats, including adherence to international health regulations and new ideas like the Coalition for Epidemic Preparedness Innovations, ${ }^{67}$ the Pandemic Emergency Financing Facility, ${ }^{51}$ and the Global Virome Project. ${ }^{68}$ WHO will have a crucial role in rethinking and modernizing surveillance systems and data analytics platforms, as well as the standards, prequalification, and procurement of essential drugs and vaccines in collaboration with the private sector.

As with the Framework Convention on Tobacco Control and The World Health Report on UHC, ${ }^{37}$ WHO will be expected to provide country guidance for future-oriented health systems and policies. Together with the World Bank and development partners, WHO should advocate for increasing DAH for the poorest countries while advising better-off members states to prepare for successful graduation from DAH through hybrid mechanisms like the Global Fund and the Global Financing Facility. ${ }^{34}$ Finally, WHO should expand the reach and quality of its advocacy and strategic communication capacity to ensure that global guidelines are clearly understood by all relevant audiences.

Internally, WHO needs to address several challenges if it is to thrive in this new world health era. It needs to define better the roles and responsibilities of its headquarters, regional, and country offices. Instead of relying only on its staff, WHO could harness today's global brain trust of experts and centers of excellence, and it should streamline the appointment of senior staff based on high-level

\section{PPPs 2.0 will be less top-down and more engaged in local markets and political economy.}

WHO needs to address several internal challenges if it is to thrive in this new world health era. 
expertise and competence rather than on geopolitical considerations. A major challenge compromising the effectiveness of WHO and threatening its independence is its budget, ${ }^{66}$ which is lower than the revenues of any large hospital in New York City-and three-quarters of the WHO budget comes from voluntary contributions. Member states' decisions to cut or increase assessed contributions will be pivotal. Finally, WHO needs to work well with the World Bank and related institutions, which can play a constructive role in financing health and development.

\section{CONCLUSIONS}

The priorities and approaches used in international health have evolved with epidemiological transitions and technological innovations. But the field has also been shaped by unprecedented economic development and a historical pendulum in the role of government in social well-being. Like the Soviet Union collapse in 1991, the Great Recession of 2008 triggered one such shift in the political economy between government and market.

Global health is moving past its stage of development assistance to a new era of country ownership and global cooperation. ${ }^{69}$ At the national level, the economic transition of health and growing political demands for social protection create conditions favorable for domestic resource mobilization and universal health coverage with new forms of private-sector engagement. At the global level, development assistance is refocused on fragile states, the poorest communities, and global public goods like health security, normativity, and innovation.

National health systems will be the center of gravity of a new world health era, and the evolving developments discussed in this article will call for adjustments in the fluid architecture of international actors and the relations within and between nation-states. This new era brings opportunities (e.g., UHC) and challenges (e.g., growing inequalities) and new ways of financing health. Leaders at all levels should understand and capitalize on this historical moment and avoid political miscalculations like those that undermined the visionary primary health care movement 40 years ago. $^{15,70}$

Acknowledgments: The authors thank Marcos Cuetos, Timothy Evans, Haileyesus Getahun, Socrates Litsios, Michael Reich, and Lesley Stone for constructive discussions of the ideas presented in earlier versions of the manuscript.
Funding: None.

Competing Interests: None declared.

\section{REFERENCES}

1. Global Burden of Disease Health Financing Collaborator Network. Future and potential spending on health 2015-40: development assistance for health, and government, prepaid private, and out-of-pocket health spending in 184 countries. Lancet. 2017;389(10083):2005-2030. CrossRef. Medline

2. United Nations (UN). The Millennium Development Goals Report 2015. New York: UN; 2015. http://www.un.org/millenniumgoals/ 2015_MDG_Report/pdf/MDG\%202015\%20rev\%20(July\%201). pdf. Accessed February 13, 2018

3. Jamison DT, Summers LH, Alleyne G, et al. Global health 2035: a world converging within a generation. Lancet. 2013; 382(9908): 1898-1955. CrossRef. Medline

4. Himelfarb T. 50 Years of Global Health, Saving Lives and Building Futures. Washington, DC: United States Agency for International Development; 2014. https://www.usaid.gov/sites/default/files/ documents/1864/USAID_50-Years-of-Global-Health.pdf. Accessed February 13, 2018

5. Garret L. Global health in a populist and nationalist age. J Int Aff March 15, 2017. https://iia.sipa.columbia.edu/global-healthpopulist-and-nationalist-age. Accessed February 13, 2018.

6. DeLong JB. Estimates of world GDP, one million B.C. - present. Berkeley, CA: University of California, Berkeley; 1998. http:// delong.typepad.com/print/20061012_LRWGDP.pdf. Accessed February 13, 2018.

7. International Macroeconomic Data Set. Washington, DC: United States Department of Agriculture; last updated December 19, 2017. https://www.ers.usda.gov/data-products/internationalmacroeconomic-data-set.aspx. Accessed February 13, 2018.

8. GNI per capita, PPP (current international \$). In: World Bank Open Data. Washington, DC: World Bank; 2018. http://data.worldbank. org/indicator/NY.GNP.PCAP.PP.CD? end $=2015 \&$ start $=1990 \&$ year_low_desc=false. Accessed February 13, 2018.

9. Pablos-Méndez A, Tabish H, de Ferranti D. The cost disease and global health. In: Baumol WJ. The Cost Disease: Why Computers Get Cheaper and Health Care Doesn't. New Haven, CT: Yale University Press; 2012.

10. United Nations Research Institute for Social Development (UNRISD). Mobilizing domestic resources for sustainable development: toward a progressive fiscal contract. In: Policy Innovations for Transformative Change: Implementing the 2030 Agenda for Sustainable Development. UNRISD Flagship Report 2016. Geneva: UNRISD; 2016:167-195. http://www.unrisd.org/80256B42004CCC77/ (httplnfoFiles)/2D9B6E61A43A7E87C125804F003285F5/\$file/ Flagship2016_FullReport.pdf. Accessed February 13, 2018.

11. Evans T, Pablos-Méndez A. Shaping of a new era for health financing. Lancet. 2016;387(10037):2482-2484. CrossRef. Medline

12. Balaam DN, Veseth MA. Political economy. Encyclopædia Britannica website. https://www.britannica.com/topic/politicaleconomy. Accessed February 13, 2018.

13. Scharf $M$. The Enlightenment and economic development. Bologna Center J Int Affairs. 2008;1 1(1):27-42. http://www. saisjournal. org/issues/vol-11-iss-1. Accessed February 13, 2018.

14. Declaration of Alma-Ata: International Conference on Primary Health Care, Alma-Ata, USSR, 6-12 September 1978. World Health Organization website. http://www.who.int/publications/almaata_ declaration_en.pdf. Accessed February 14, 2018.

15. Brown TM, Cueto M, Fee E. The World Health Organization and the transition from international to global public health. Am J Public Health. 2006;96(1):62-72. CrossRef. Medline 
16. Beaglehole R, Bonita R. Global public health: a scorecard. Lancet. 2008;372(9654):1988-1996. CrossRef. Medline

17. Yamey G. WHO in 2002: Faltering steps towards partnerships. BM. 2002;325(7374):1236-1240. CrossRef. Medline

18. Walt G. Globalisation of international health. Lancet. 1998;351(9100):434-437. CrossRef. Medline

19. Williamson J. What Washington means by policy reform. In: Williamson J, editor. Latin American Readjustment: How Much Has Happened. Washington, DC: Institute for International Economics; 1989.

20. Yach D, Bettcher D. The globalization of public health, I: threats and opportunities. Am J Public Health. 1998;88(5):735-738, discussion 742-744. CrossRef. Medline

21. Godlee F. WHO in retreat: is it losing its influence? BMJ. 1994;309(6967):1491-1495. CrossRef. Medline

22. Fidler D. A theory of open-source anarchy. Indiana J Glob Leg Stud. 2008;15(1):259-284. http://ijgls.indiana.edu/1501/a-theory-ofopen-source-anarchy/. Accessed March 7, 2018.

23. Walt G. WHO under stress: implications for health policy. Health Policy. 1993;24(2):125-144. CrossRef. Medline

24. Fidler DP. Architecture amidst anarchy: global health's quest for governance. Glob Health Gov. 2007;1(1). http://ghgi.org/Fidler_ Architecture.pdf. Accessed February 21, 2018.

25. International Monetary Fund (IMF). World Economic Outlook. April 2009: Crisis and Recovery. Washington, DC: IMF; 2009 http://www.imf.org/external/pubs/ft/weo/2009/01/. Accessed February 21, 2018.

26. Piketty T. Capital in the Twenty-First Century. Cambridge, MA and London, UK: Belknap Press of Harvard University Press; 2014.

27. Mishra P. Age of Anger: A History of the Present. New York: Farrar, Straus and Giroux; 2017.

28. Racism, Xenophobia Increasing Globally, Experts Tell Third Committee, amid Calls for Laws to Combat Hate Speech, Concerns over Freedom of Expression [meetings coverage]. New York: United Nations; November 1, 2016. https://www.un.org/press/ en/2016/gashc4182.doc.htm. Accessed February 13, 2018.

29. Dalio R, Kriger S, Rogers J, Davis G. Populism: the phenomenon. Bridgewater Daily Observations. March 22, 2017. https://www. bridgewater.com/resources/bwam032217.pdf. Accessed February 13, 2018.

30. Dornbusch R, Edwards S. The macroeconomics of populism. In: Dornbusch R, Edwards S, editors. The Macroeconomics of Populism in Latin America. Chicago: University of Chicago Press; 1991. http://www.nber.org/chapters/c8295.pdf. Accessed February 13, 2018.

31. Gostin LO, Tomori O, Wibulpolprasert S, et al. Toward a common secure future: four global commissions in the wake of Ebola. PLOS Med. 2016;13(5):e1002042. CrossRef. Medline

32. United Nations. Addis Ababa Action Agenda of the Third International Conference on Financing for Development. New York United Nations; 2015. http://www.un.org/esa/ffd/wp-content/ uploads/2015/08/AAAA_Outcome.pdf. Accessed February 14, 2018.

33. World Bank. Financing UHC: resource mobilization [discussion paper]. Washington, DC: World Bank; 2017.

34. Jacovella D, Evans TG, Claeson M, Kagia R, Pablos-Méndez A. Global Financing Facility: where will the funds come from? Lancet. 2016;387(10014):121-122. CrossRef. Medline

35. Guarnaschelli S, Lampert S, Marsh E, Johnson L. Innovative financing for development: scalable business models that produce economic, social, and environmental outcomes. New York: Innovative Financing Initiative, Global Development Incubator; 2014. http:// globaldevincubator.org/innovative-financing-for-development/. Accessed February 14, 2018

36. Lin A, Wilson J. Healthy Markets for Global Health: A Market Shaping Primer. Washington, DC: Center for Accelerating Innovation and Impact, United States Agency for International Development; 2014. https://uww.usaid.gov/cii/market-shapingprimer. Accessed February 14, 2018.

37. World Health Organization (WHO). Health Systems Financing: The Path to Universal Coverage. World Health Report 2010. Geneva: WHO; 2010. http://www.who.int/whr/2010/en/. Accessed February 14, 2018.

38. World Health Organization (WHO); World Bank. Tracking Universal Health Coverage: 2017 Global Monitoring Report. Geneva and Washington, DC: WHO and International Bank for Reconstruction and Development, World Bank; 2017. http://www. who.int/healthinfo/universal_health_coverage/report/2017/en/. Accessed February 14, 2018

39. Garrett L, Chowdhury AMR, Pablos-Méndez A. All for universal health coverage. Lancet. 2009;374(9697):1294-1299. CrossRef. Medline

40. Frenk J. Leading the way towards universal health coverage: a call to action. Lancet. 2015;385(9975):1352-1358. CrossRef. Medline

41. International Labour Organization (ILO). Addressing the global health crisis: universal health protection policies. Social Protection Policy Paper 13. Geneva: ILO; 2017. http://www.social-protection. org/gimi/gess/RessourcePDF.action?ressource.ressourceld= 48277. Accessed February 14, 2018.

42. UHC2030. Healthy Systems for Universal Health Coverage: A Joint Vision for Healthy Lives. Geneva and Washington, DC: World Health Organization and International Bank for Reconstruction and Development, World Bank; 2017. https://www.uhc2030.org/ news-events/uhc2030-news/article/healthy-systems-for-universal health-coverage-a-joint-vision-for-healthy-lives-406553/. Accessed February 14, 2018.

43. United Nations General Assembly. Resolution adopted by the General Assembly on 12 December 2012: Global health and foreign policy. A/Res/67/81. March 14, 2013. http://www.un. org/en/ga/search/view_doc.asp? symbol=A/RES/67/81. Accessed February 14, 2018.

44. Pablos-Mendez A, Cavanaugh K, Ly C. The new era of health goals: universal health coverage as a pathway to the Sustainable Development Goals. Health Systems Reform. 2016;2(1):15-17. CrossRef

45. Universal Health Coverage Forum 2017: "Tokyo Declaration on Universal Health Coverage: All Together to Accelerate Progress towards UHC" [statement]. World Bank website. December 14, 2017. http://www.worldbank.org/en/news/statement/2017/12/ 14/uhc-forum-tokyo-declaration. Accessed February 14, 2018.

46. The Busan Partnership for Effective Development Co-operation: Fourth High Level Forum on Aid Effectiveness, Busan, Republic of Korea, 29 November-1 December 2011. Organisation for Economic Co-operation and Development website. http://www. oecd.org/dac/effectiveness/49650173.pdf. Accessed February $14,2018$.

47. Kharas H. Financing for Development: International Financing Flows After 2015. Washington, DC: Brookings Institution; 2014. https:// www.brookings.edu/research/financing-for-developmentinternational-financial-flows-after-2015/. Accessed February 14, 2018.

48. Chowdhry RG, Perkins S, Armstrong L, Patel B. Graduation and phase-out in the health sector: what have we learned? Washington, DC: United States Agency for International Development; 2012. http://pdf.usaid.gov/pdf_docs/PBAAA917.pdf. Accessed February 14, 2018. 
49. Moon S, Røttingen JA, Frenk J. Global public goods for health: weaknesses and opportunities in the global health system. Health Econ Policy Law. 2017;12(2):195-205. CrossRef. Medline

50. Sands P, Mundaca-Shah C, Dzau VJ. The neglected dimension of global security: a framework for countering infectious-disease crises. N Engl J Med. 2016;374(13):1281-1287. CrossRef. Medline

51. Røttingen JA, Gouglas D, Feinberg $M$, et al. New vaccines against epidemic infectious diseases. NEngl J Med. 2017;376(7):610-613. CrossRef. Medline

52. World Bank Group Launches Groundbreaking Financing Facility to Protect Poorest Countries against Pandemic [press release]. Washington, DC: World Bank; May 21, 2016. http://www. worldbank.org/en/news/press-release/2016/05/21/worldbank-group-launches-groundbreaking-financing-facility-to-protectpoorest-countries-against-pandemics. Accessed February 14, 2018.

53. Kickbusch I. BRICS contributions to the global health agenda. Bull World Health Organ. 2014;92(6):463-464. CrossRef. Medline

54. World Health Organization (WHO). World Health Statistics 2016 : Monitoring Health for the SDGs, Sustainable Development Goals. Geneva; WHO; 2016. http://www.who.int/gho/publications/ world_health_statistics/2016/en/. Accessed February 14, 2018

55. GBD 2015 Mortality and Causes of Death Collaborators. Global, regional, and national life expectancy, all-cause mortality, and cause-specific mortality for 249 causes of death, 1980-2015: a systematic analysis for the Global Burden of Disease Study 2015 Lancet. 2016;388(10053):1459-1544. CrossRef. Medline

56. United Nations General Assembly. Resolution adopted by the General Assembly on 10 July 2014. Outcome document of the high level meeting of the General Assembly on the comprehensive review and assessment of the progress achieved in the prevention and control of non-communicable diseases. A/Res/68/300. July 17, 2014. http://wnw. who.int/nmh/events/2014/a-res-68-300.pdf. Accessed February 14, 2018.

57. Allen LN, Pullar J, Wickramasinghe K, et al. Are WHO "best buys" for non-communicable diseases effective in low-income and lowermiddle-income countries? A systematic review. Lancet Glob Health. 2017;5(suppl 1):S17. CrossRef

58. International Finance Corporation. The Business of Health in Africa: Partnering with the Private Sector to Improve People's Lives. Washington, DC: International Finance Corporation, World Bank
Group; 2007. https://www unido.org/sites/default/files/201601/IFC_HealthinAfrica_Final_0.pdf. Accessed February 14, 2018.

59. Lagomarsino G, de Ferranti D, Pablos-Mendez A, Nachuk S, Nishtar S, Wibulpolprasert S. Public stewardship of mixed health systems. Lancet. 2009;374(9701):1577-1578. CrossRef. Medline

60. Reeves A, Gourtsoyannis Y, Basu S, McCoy D, McKee M, Stuckler D. Financing universal health coverage-effects of alternative tax structures on public health systems: cross-national modelling in 89 low-income and middle-income countries. Lancet. 2015; 386(9990):274-280. CrossRef. Medline

61. Piot $P$, Quinn TC. Response to the AIDS pandemic: a global health model. N Engl J Med. 2013;368(23):2210-2218. CrossRef. Medline

62. Smith J, Buse K, Gordon C. Civil society: the catalyst for ensuring health in the age of sustainable development. Global Health. 2016;12(1):40. CrossRef. Medline

63. Sixty-Ninth World Health Assembly: Framework of engagement with non-State actors. World Health Organization website. May 28, 2016. http://www. who.int/about/collaborations/non-stateactors/en/. Accessed February 14, 2018.

64. Moon S. WHO's role in the global health system: what can be learned from global R\&D debates? Public Health. 2014;128(2):167172. CrossRef. Medline

65. Pablos-Méndez A, Baker S. A new leader for a new world health. Am J Public Health. 2016;106(11):1907-1908. CrossRef. Medline

66. Vaughan JP, Mogedal S, Kruse SE, Lee K, Walt G, de Wilde K. Financing the World Health Organisation: global importance of extrabudgetary funds. Health Policy. 1996;35(3):229-245. CrossRef. Medline

67. Brende B, Farrar J, Gashumba D, et al. CEPI-a new global R\&D organisation for epidemic preparedness and response. Lancet. 2017;389(10066):233-235. CrossRef. Medline

68. Carroll D, Daszak P, Wolfe ND, et al. The Global Virome Project Science. 2018; 359(6378):872-874. CrossRef. Medline

69. Frenk J, Gómez-Dantés $O$, Moon S. From sovereignty to solidarity: a renewed concept of global health for an era of complex interdependence. Lancet. 2014;383(991 1):94-97. CrossRef. Medline

70. Jong-wook L. Global health improvement and WHO: shaping the future. Lancet. 2003;362(9401):2083-2088. CrossRef. Medline

\section{Peer Reviewed}

Received: July 28, 2017; Accepted: January 16, 2018; First Published Online: March 14, 2018

Cite this article as: Pablos-Méndez A, Raviglione MC. A new world health era. Glob Health Sci Pract. 2018;6(1):8-16. https://doi.org/10.9745/ GHSP-D-17-00297

(C) Pablos-Méndez and Raviglione. This is an open-access article distributed under the terms of the Creative Commons Attribution 4.0 International License (CC BY 4.0), which permits unrestricted use, distribution, and reproduction in any medium, provided the original author and source are properly cited. To view a copy of the license, visit http://creativecommons.org/licenses/by/4.0/. When linking to this article, please use the following permanent link: https://doi.org/10.9745/GHSP-D-17-00297 